\title{
A Novel Proliferation-Associated Variant of CFR-1 Defined by a Human Monoclonal Antibody
}

\author{
Frank Hensel, Stephanie Brändlein, Matthias Eck, Karsten Schmidt, Veit Krenn, \\ Astrid Kloetzer, Angela Bachi, Matthias Mann, Hans Konrad Müller-Hermelink, and \\ H. Peter Vollmers
}

\author{
Institute of Pathology (FH, SB, ME, AK, HKM-H, HPV) and Chirugische Klinik und Poliklinik (KS), University of \\ Würzburg, Würzburg; Institute of Pathology (VK), University Hospital Charité, Berlin; and European Molecular \\ Biology Laboratory (AB, MM), Heidelberg, Germany
}

\begin{abstract}
SUMMARY: The germline coded human monoclonal IgM antibody 103/51 was isolated from a gastric carcinoma patient. This antibody binds to a 130-kd membrane molecule and has a mitotic effect on tumor cells in vitro. To characterize the target, we sequenced the protein and showed that the antibody binds to the cysteine-rich fibroblast growth factor receptor (CFR)-1, which is highly homologous to MG-160 and the E-selectin-ligand (ESL)-1. The epitope was determined by glycosidase-digestion experiments to be an $\mathrm{N}$-linked carbohydrate side chain. Immunohistochemistry was used to investigate the tissue distribution of CFR-1. Different healthy tissues were tested and only the collecting tubes of the kidney, the Golgi apparatus, and the glomerular and fascicular zones of the adrenal gland stained positive. However, on malignant tissue the receptor is overexpressed in nearly all tested stomach cancers (12 of 15) and other tested carcinomas (13 of 15). Most interestingly, the receptor is also present in Helicobacter pylori gastritis and gastric dysplasia, but absent on uninflamed stomach mucosa. This restricted tissue pattern indicates that antibody 103/51 reacts with a membrane-bound variant of CFR-1, which is mainly expressed on transformed cells and precursor lesions and is essential for proliferation processes. The possible activity of antibody 103/51 as an activating ligand in these proliferative changes of gastric epithelial mucosa is discussed. (Lab Invest 2001, 81:1097-1108).
\end{abstract}

$T$

he occurrence of autoantibodies that react with altered or overexpressed cellular structures or oncogene products is frequently observed in cancer patients (Tomer et al, 1998). It is well documented that these autoantibodies are against altered structures like overexpressed or mutated oncogenes, such as p53 (Schlichtholz et al, 1992; Winter et al, 1992), ras (Takahashi et al, 1995), L-myc (Yamamoto et al, 1996), receptors like c-erbB (Pupa et al, 1993), structural proteins (Fernandez-Madrid et al, 1996), or overexpressed differentiation markers (Velikova et al, 1997). Often, these autoantibodies have been proved to be of diagnostic and prognostic value (Peyrat et al, 1995). In general, antibodies, like other proteins, are capable of mimicking ligand effects by stimulating growth factor receptors (Rajkumar and Gullick, 1994) or inducing apoptosis (Hensel et al, 1999a). Autoantibodies have also been shown to influence growth of gastric carcinoma cells and might be involved in the initiation and propagation of stomach carcinogenesis (Hensel et al, 1999b; Negrini et al, 1996), which might be harmful to the organism.

Received April 3, 2001.

This project was in part supported by the Deutsche Forschungsgemeinschaft (Grant Vo 469/3).

Address reprint requests to: Dr. H. Peter Vollmers, Institut für Pathologie, Universität Würzburg, Josef-Schneider-Str. 2, D-97080 Würzburg, Germany.E-mail:path027@mail.uni-wuerzburg.de
The development of stomach cancer is a multistep and multifactoral process (Correa, 1992). Although little is known about molecular mechanisms, factors such as high salt intake, alcohol, nitrosamines, and infection with the bacterium Helicobacter pylori $(H$. pylori) are clearly proved to be involved in the initiation of stomach carcinogenesis. Due to a strong correlation between $H$. pylori infection and the occurrence of gastritis, dysplasia, and development of gastric cancer, the bacterium has been classified as a class I carcinogen by the World Health Organization (Logan, 1994). H. pylori directly induces serious precancerous cellular changes in the mucosal environment and is also responsible for the increase of autoantibodies, which are frequently observed in gastritis and stomach cancer patients (Negrini et al, 1996). These antibodies are able to induce gastric lesions and apoptosis in the gastric epithelium (Steininger et al, 1998). So far the nature of the antigens is only partly known. Antibodies against the gastric $\mathrm{H}+/ \mathrm{K}(+)$-ATPase (Claeys et al, 1998), Interleukin-8 (Crabtree et al, 1993; Ma et al, 1994), and Lewis blood group antigens (Appelmelk et al, 1997) are frequently found in gastritis and stomach cancer.

In recent publications, we described that the human antibody 103/51, which was isolated from a stomach cancer patient with diffuse-type adenocarcinoma, crossreacts with $H$. pylori and stomach cancer cells (Vollmers et al, 1994). The antibody has a mitotic effect on stomach carcinoma cells in vitro by binding to a 
130-kd membrane receptor (Hensel et al, 1999b). Sequencing of the antibody's variable gene regions identified the antibody 103/51 as an autoantibody. Immunohistochemistry shows that the antibody reacts strongly with stomach cancer cells and with some glandular stomach tissue.

In this paper, we describe that the approximately $130-k d$ antigen of antibody 103/51 was identified to be cysteine-rich fibroblast growth factor receptor (CFR)-1, a multifunctional protein that is highly homologous to the E-selectin-ligand (ESL)-1 (Steegmaier et al, 1995) and MG-160 (Gonatas et al, 1989). This epitope was determined to be an $\mathrm{N}$-linked carbohydrate residue. By more detailed immunohistochemistry, we show that CFR-1 is specifically overexpressed on transformed and/or proliferating cells.

\section{Results}

\section{Purification and Identification of Antigen 103/51}

Western blot analysis was used to show that the antibody $103 / 51$ binds to an approximately 130-kd membrane protein on stomach cancer cells. We prepurified this protein by sequential size exclusion and anion exchange chromatography (Fig. 1a). The protein was excised from a Coomassie-stained preparative SDS-PAGE. One part was used for production of mouse monoclonal antibodies (see below) and one part was used to identify the protein by the method outlined by Shevchenko et al (1996a). After 3 hours of in-gel digestion with trypsin, about $1 \%$ of the total digested volume was removed and subjected to high mass accuracy matrix-assisted laser desorption/ionization (MALDI) peptide mass mapping (saving the rest of the digest for nanoelectrospray analysis, in case MALDI MS did not lead to definitive identification). Despite the femtomole amount of the protein digest consumed for MALDI analysis, a database search matched 35 peptides to the CFR- 1 sequence with a mass accuracy within $50 \mathrm{ppm}$. These peptides cover $29 \%$ of the CFR-1 sequence, thus definitively identifying the protein, which has a calculated molecular weight of approximately $134 \mathrm{kd}$ (Burrus et al, 1992) (Fig. 1b).

\section{Effect of Transient Transfection of Cell Line 23132 with CFR Antisense Vector on Binding of Antibody 103/51 and Live Cell Staining}

We investigated the effect of an antisense transfection of the stomach carcinoma cell line 23132 by immunohistochemistry and flow cytometry. For this, a 897-bp PCR fragment of CFR, flanking the region between base pairs 802 and 1699, was cloned into the pHOOK-2 vector in an antisense direction relative to the CMV promoter. Subconfluently grown cells were transiently transfected with the pHOOK-CFR antisense vector, pHOOK-lacZ, and pHOOK vector. Transfection was controlled by a $\beta$-galactosidase assay (data not shown). Forty-eight hours after transfection, cytospin preparations were prepared and stained with antibodies 103/51 and anticytokeratin 18 as a control (not shown).

The immunohistochemistry showed a clear reduction of staining in cells transfected with the pHOOKCFR antisense vector when compared with mocktransfected cells (Fig. 2, a and b). This confirmed the binding of antibody $103 / 51$ to CFR-1. The slight cytoplasmatic staining visible in both stainings might be due to nonspecific binding often observed in staining with human IgM antibodies on acetone-fixed cells. Membrane expression and the effect of transfection were also tested by flow cytometry (Fig. 2, g to i). The data indicate a reduction in binding of the antibody $103 / 51$ after transfection of cells with the CFR-1

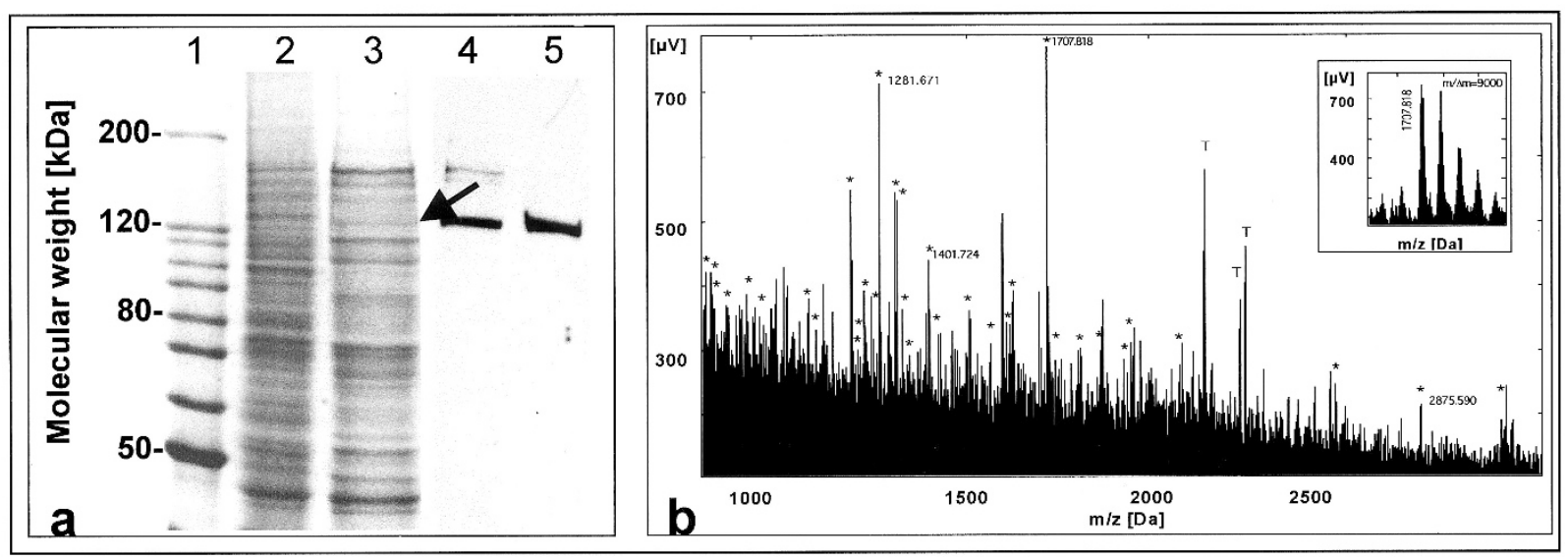

Figure 1.

Identification of the antigen of antibody 103/51. a, Protein purification of the antigen from membrane extracts of stomach carcinoma cell line 23132. Membrane fractions were processed by chromatographic procedures and whole membrane fraction (Lane 2), or purified proteins (Lane 3) were stained with Coomassie (Lane 1: 10 kd ladder). Western blot analysis with antibody 103/51 on membrane fractions of cell line 23132 showed one main band with a molecular weight of approximately $130 \mathrm{kd}$ (Lane 4). Specificity of processed membrane extracts was controlled by Western blotting with 103/51 (Lane 5). The protein band indicated by the arrow was excised from a preparative gel and used for matrix-assisted laser desorption/ionization (MALDI) mass mapping and immunization of mice. b, Identification of the 130-kd gel-separated protein by high resolution MALDI peptide mass mapping. Peaks labeled with asterisks ( ${ }^{\star}$ ) match the calculated masses of tryptic peptides of U28811 human cysteine-rich fibroblast growth factor receptor (CFR-1) with a mass accuracy better than 50 ppm. Peaks labeled with $T$ correspond to trypsin autolysis products. The inset shows the mass resolution $(\mathrm{m} / \Delta \mathrm{m}=9000)$ of the peak at $\mathrm{m} / \mathrm{z} 1707.818$. 

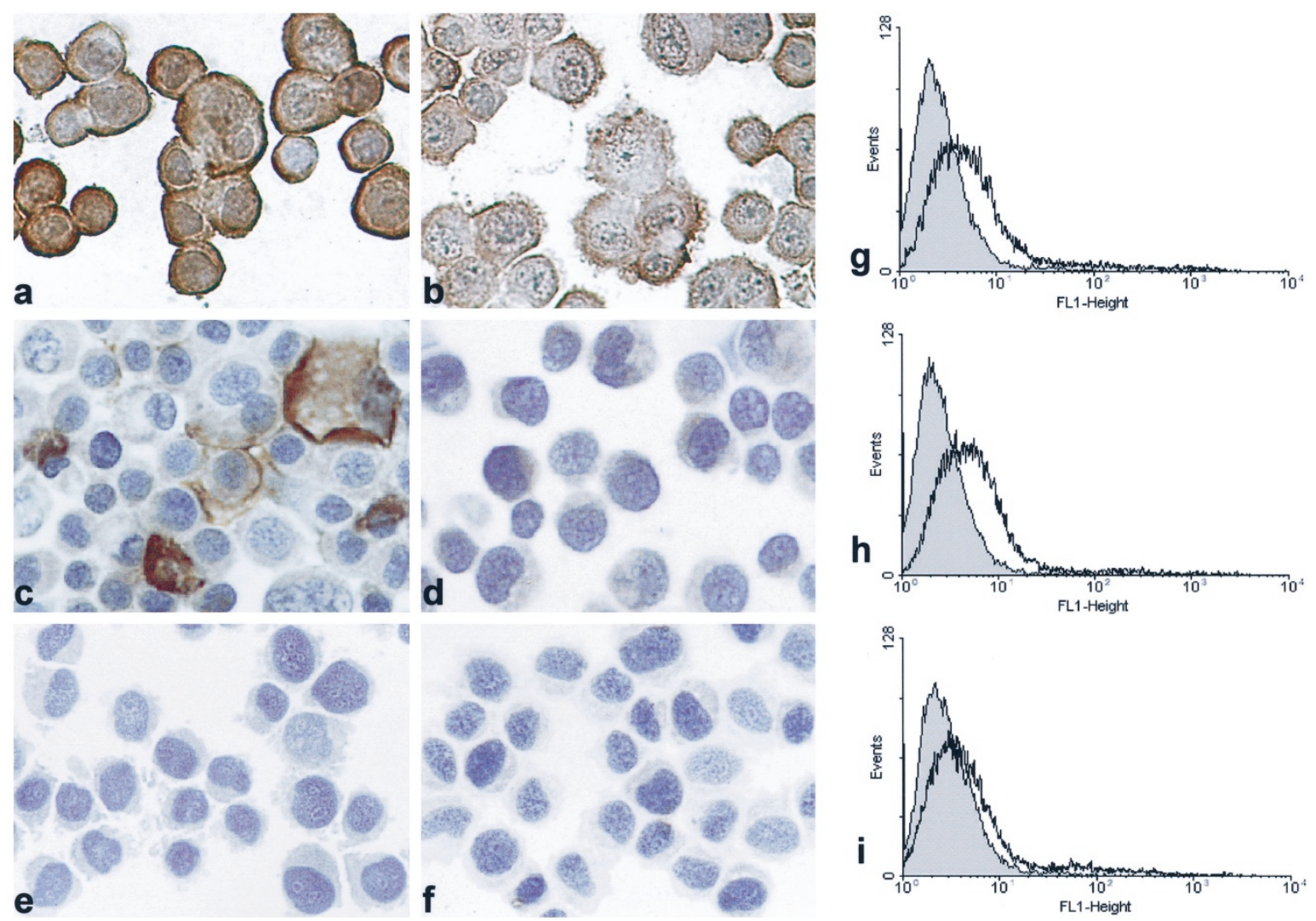

Figure 2.

Effect of CFR-1 antisense transfection on antibody 103/51 staining and live cell staining (original magnification, $\times 200$ ). a, Cell line 23132 transiently transfected with control vector and acetone fixation shows intensive staining with antibody 103/51. b. Reduced staining is visible in cells transiently transfected with CFR-1 antisense vector. c, To reduce background staining in immunohistochemical staining, live cell staining was performed with cell line 23132 . A clear membrane staining is visible. d, Control live cell staining (only secondary antibody) on cell line 23132. e, Negative live cell staining on cell line Colo-699 with antibody 103/51 indicates that this cell line is negative for expression of CFR-1. f, Control live cell staining (only secondary antibody) on cell line Colo-699. g, Flow cytometry of cell line 23132 with antibodies Chromopure human IgM (gray) and 103/51. h, Analysis of cells transfected with control vector pHOOK-2 with flow cytometry 48 hours after transfection. i, Cells transfected with CFR-1 antisense vector shows a clear decrease in binding of antibody 103/51.

antisense vector. However, untreated cells or cells transfected with the control vector pHOOK-2 show a clear binding to cell line 23132, indicating expression of CFR-1 on the cell membrane.

To investigate the specific membrane distribution of the CFR-1 isoform, we performed live cell staining with cell line 23132 and some nonstomach-cancer cell lines. On the cell line 23132 we found a clear staining (Fig. 2, c and d), whereas the human lung adenocarcinoma cell lines Colo-699 (Fig. 2, e and f) and human epidermoid lung carcinoma cell line EPLC-272H (not shown) were clearly negative. These data show that the described CFR-1 isoform is not expressed in all cancerous cell lines, and the exclusive membrane staining of 23132 cells indicates that the CFR- 1 isoform seems to have a distribution different from the one described so far for CFR-1.

\section{Glycosidase Assay}

CFR-1 is a sialoglycoprotein with five possible $\mathrm{N}$-glycosylation sites; it has been shown by treatment with glycosidase $\mathrm{F}$ that the molecule is glycosylated at these sites (Steegmaier et al, 1995). Because tumorreactive antibodies often react with carbohydrate residues, we investigated whether this is the case for the antibody 103/51. Cytospin preparations of cell line 23132 were incubated for 4 hours with $\mathrm{O}-$ and $\mathrm{N}$-glycosidases, and then subjected to immunohistochemical staining with antibody 103/51. Treatment of cells with $\mathrm{N}$-glycosidase led to a dramatic decrease in 103/51 staining (Fig. 3b), whereas incubation with dephosphorylation buffer (Fig. 3a) or digestion with O-glycosidase (not shown) had no effect on binding of the antibody $103 / 51$. This shows that the specificity of binding of the antibody 103/51 must be located in sugar residues and not in the primary protein sequence.

To further control for this effect, membrane extracts of cell line 23132 were declycosylated for 16 hours and Western blots were prepared and stained with antibody $103 / 51$. We found a reduction in the reaction on lysates incubated with $\mathrm{N}$-glycosydase when compared with the control lysates (Fig. 3c).

\section{Production of Murine Antibodies and Immunohistochemical Staining of Paraffin Section of Stomach Adenocarcinoma}

Because commercial antibodies to CFR-1 are not available, we immunized mice with purified protein eluated from Coomassie-stained SDS-gel for produc- 

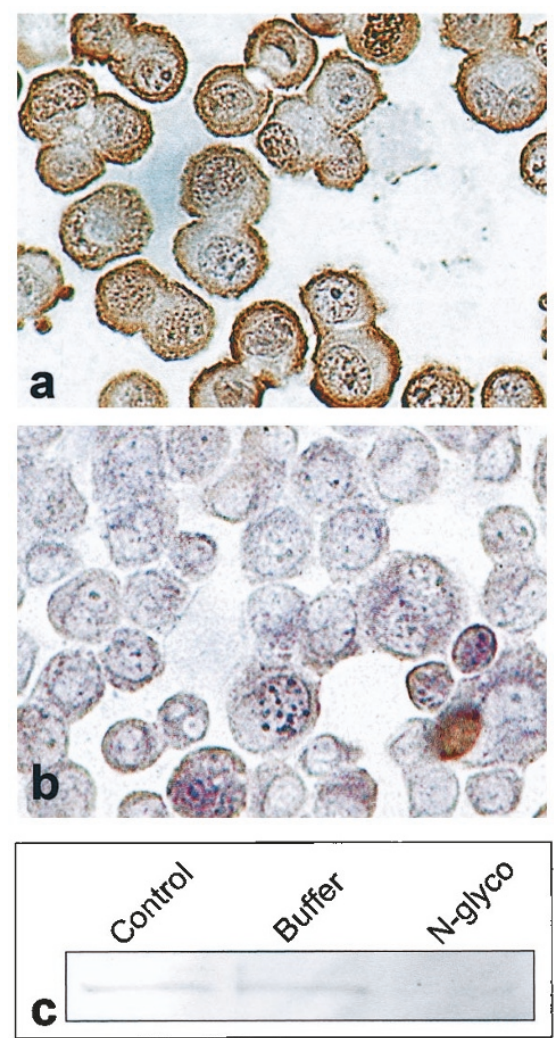

Figure 3.

Effect of deglycosylation of staining with antibody 103/51. a, Cells (23132) incubated with deglycosylation buffer and acetone-fixed show intense staining with antibody 103/51. b, Cells (23132) treated with $\mathrm{N}$-glycosidase followed by acetone fixation show a clear reduction in staining. c, Effect of deglycosylation of membrane extracts of cell line 23132 on reaction with antibody 103/51 in Western blot analysis. Extracts incubated for 16 hours with deglycosylation buffer (Buffer) show no difference in staining to untreated extracts (Contro). Incubation with $\mathrm{N}$-glycosidase leads to a clear reduction in staining $(\mathrm{N}-\mathrm{g} / \mathrm{yco})$. tion of monoclonal antibodies to strengthen the specificity and to further characterize CFR-1 expression. Spleen cells were immortalized by fusion with the heteromyeloma NSO. One hundred and fifty clones were tested for immunohistochemical staining. Positive clones were recloned, and the clone 58/47-69 ( $\operatorname{lgM})$ was used for further characterization. To investigate the binding properties of the human antibody $103 / 51$ and the murine antibody 58/47-69, we stained paraffin sections of 15 different stomach adenocarcinoma and one adenoma. Identical staining of glandular cells of the normal epithelial tissue and intensive staining of carcinoma cells was found (Fig. 4). In short, early carcinoma $(n=2)$ were stained by both antibodies. On intestinal-type carcinoma, both antibodies stained in 4 of 5 cases. On diffuse-type carcinoma, all cases $(n=4)$ were stained, and the intermediary-type were positive in $50 \%(n=4)$ with both antibodies. These results show a high expression of CFR-1 in most cases of stomach carcinoma. The investigated adenoma showed a distinct staining pattern, with positive cells only in the transition from normal to transformed cells.

\section{Immunohistochemical Staining with Antibody 103/51 on Gastric Mucosa}

To investigate the reaction pattern of antibody 103/51 on gastric mucosa in more detail, we performed immunohistochemical stainings on gastric tissue without inflammation, H. pylori-associated chronic active gastritis, high-grade dysplasia, and gastric adenocarcinoma. On uninflamed gastric tissue, no reaction was seen (Fig. 5). However, in the mucosa of a patient with $H$. pylori gastritis we found staining predominantly in
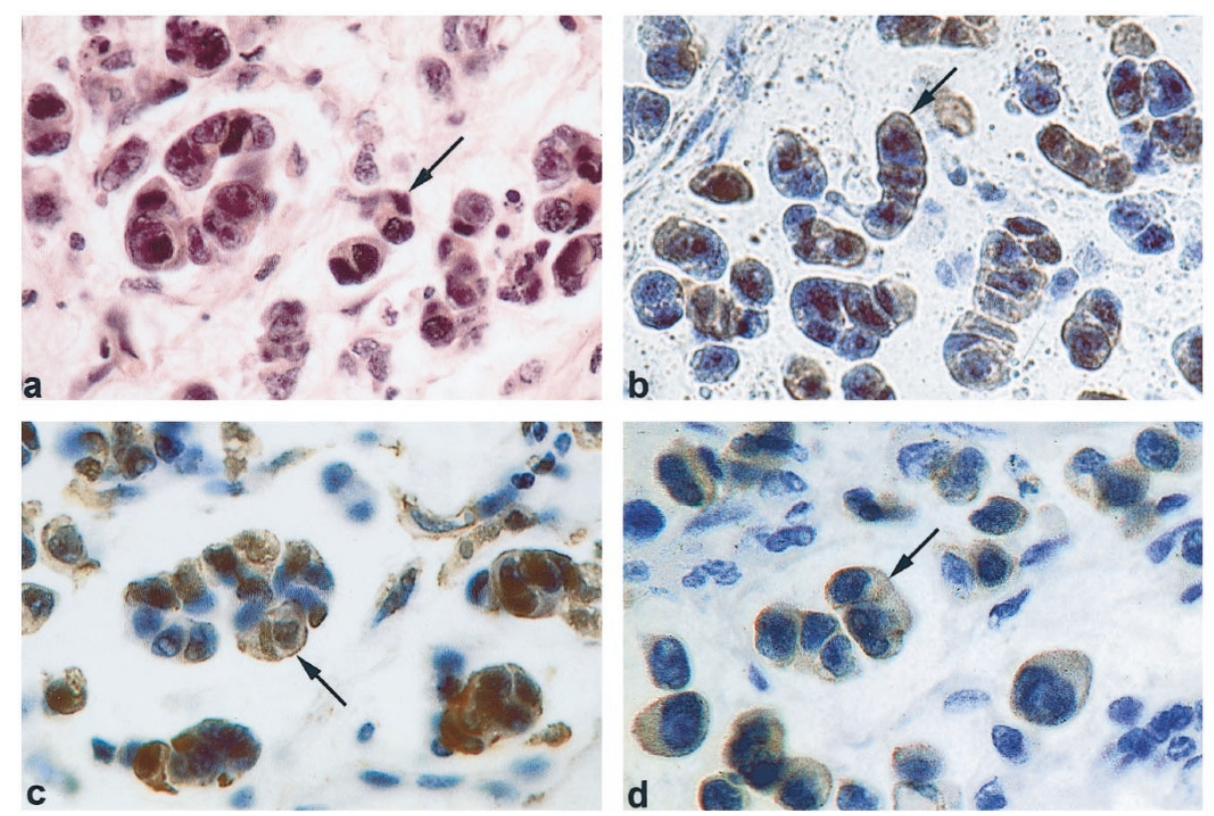

Figure 4.

Immunohistochemical staining with murine antibody 58/47-69 and 103/51 on stomach adenocarcinoma. To show identical specificity of antibody 103/51 and murine antibody 58/47-69, diffuse-type stomach adenocarcinoma was stained with hematoxylin-eosin (a), antibodies 103/51 (b) and 58/47-69 (c), and anticytokeratin 18 as a positive control. Identical staining in Panels $\mathrm{c}$ and $\mathrm{d}$ indicates identical specificity (arrows point to tumor cells). 
HE-staining
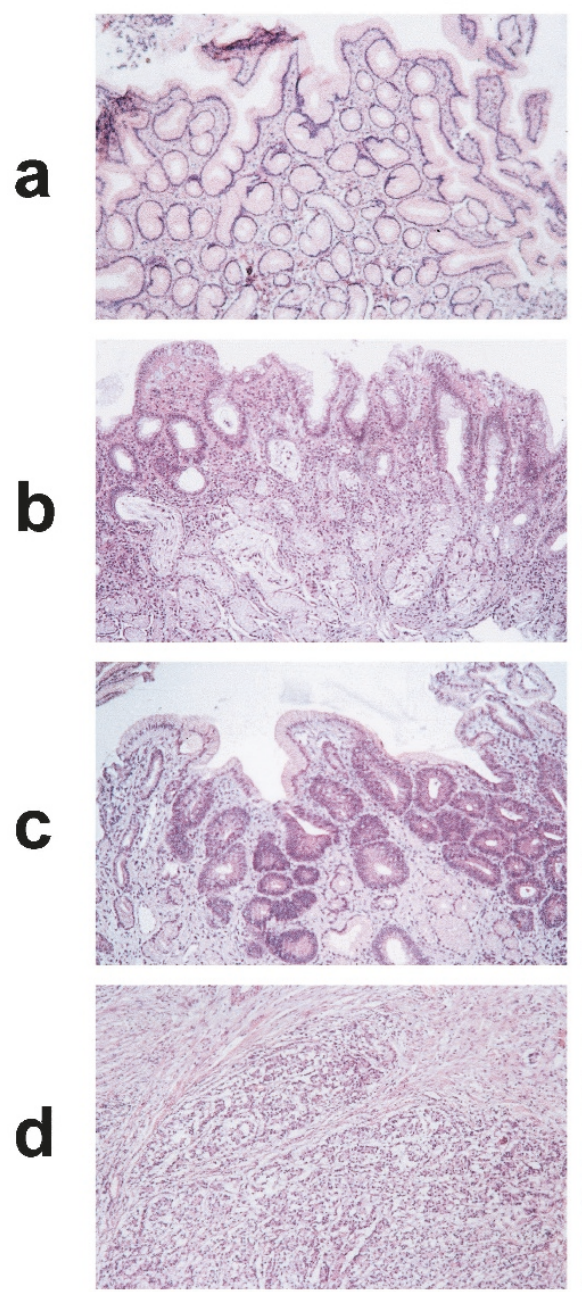

Ki67
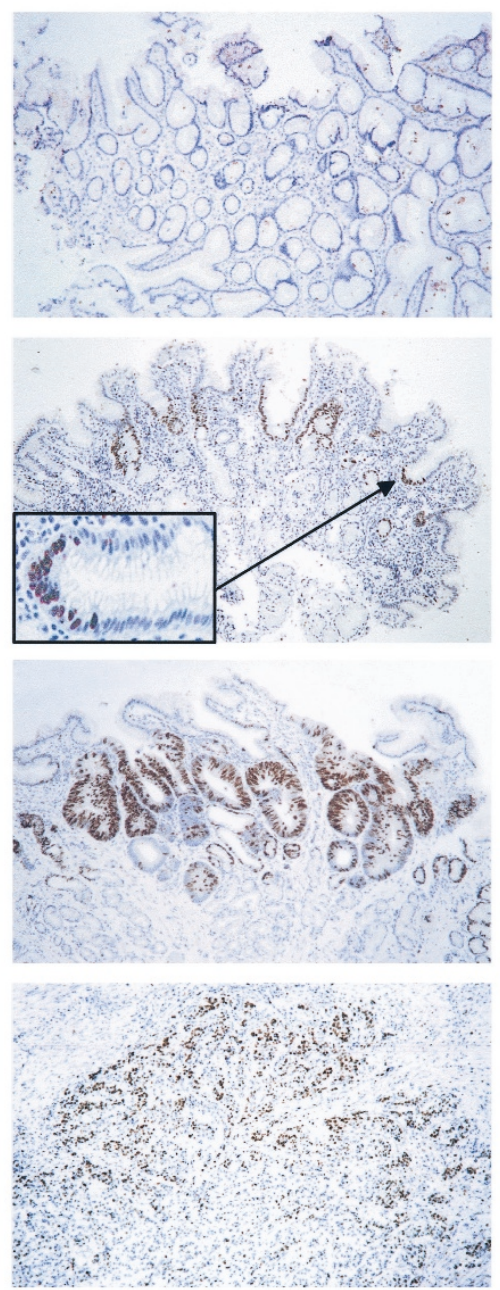

$103 / 51$
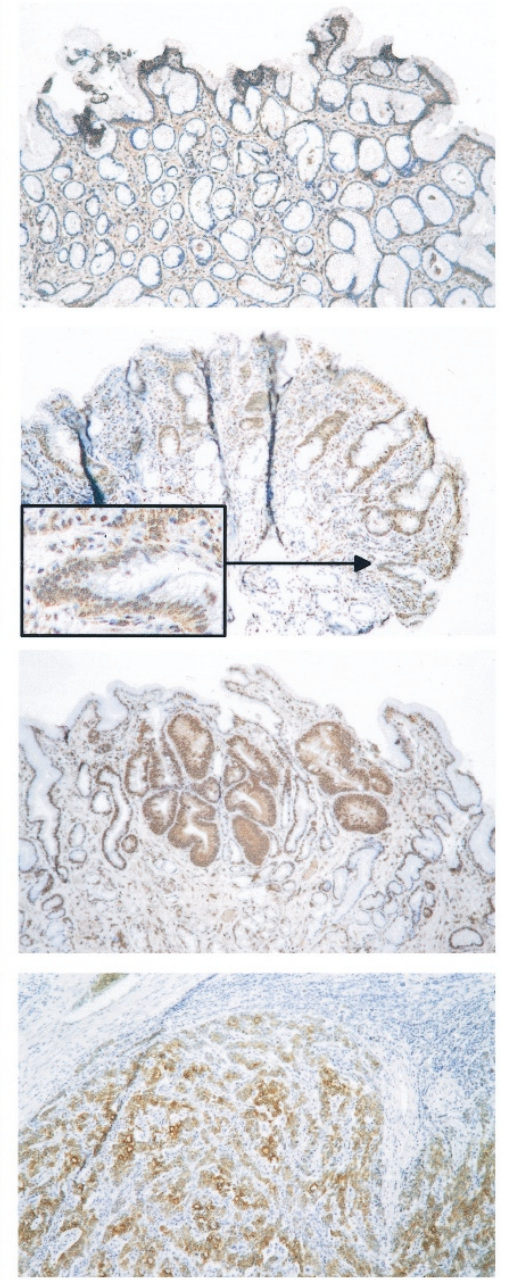

Figure 5.

Immunohistochemical staining of antibody 103/51 on different gastric tissues. Cryosections of gastric tissues were stained with hematoxylin-eosin, antibody Ki67 (to indicate proliferating cells), and antibody 103/51 (original magnification, $\times 100$ ). a, Gastric tissue with inflammation; b, H. pylori-induced gastritis (insets show enlargement of marked glands); c, dysplasia; d, gastric adenocarcinoma.

the basal zone of foveolar cells. The staining pattern of antibody 103/51 shows a strong correlation with the activation pattern shown by Ki67 staining (Ramires et al, 1997). A more intensive staining of antibody 103/51 was seen in the proliferation zone of gastric dysplasia also correlating with Ki67 staining. The strongest staining was found in the proliferating zone of gastric adenocarcinoma.

\section{Immunohistochemical Staining of Antibodies 103/51 and 58/47-69 on Different Tissues}

We investigated the expression of CFR-1 in other cancerous and normal tissues by immunohistochemical staining of paraffin sections with antibodies 103/51 and 58/47-69. Of 15 cancerous tissues (different from stomach carcinoma), antibody 103/51 showed staining in 13 cases (Fig. 6, Table 1). Negative staining was observed on anaplastic cells of the lung, confirming the results from the immunohistochemical staining and MTT-assay with the cell lines Colo-699 and EPLC-272H. This data indicates an overexpression of CFR-1 and distribution to the cell membrane in malignant transformed cells.

On 28 normal tissues tested, we found a restricted expression on only three intestinal organs (Table 2). Membrane staining was observed on the glandular foveola of the stomach and the glomerular and fascicular zones of the adrenal gland, whereas staining of the Golgi apparatus was found in the collecting tubes of the kidney (Fig. 5). This further confirms the characterization of the antigen as CFR-1, which has been described earlier by Burrus et al (1992).

\section{Stimulation with Human and Murine Monoc/onal Antibodies}

As stated in our previous publications (Vollmers et al, 1994; Hensel et al, 1999b), the antibody 103/51 leads to the stimulation of cell line 23132 in vitro. We measured the stimulating ao antibody 103/51 with the mitochondrial hydroxylase assay (MTT), which is a 

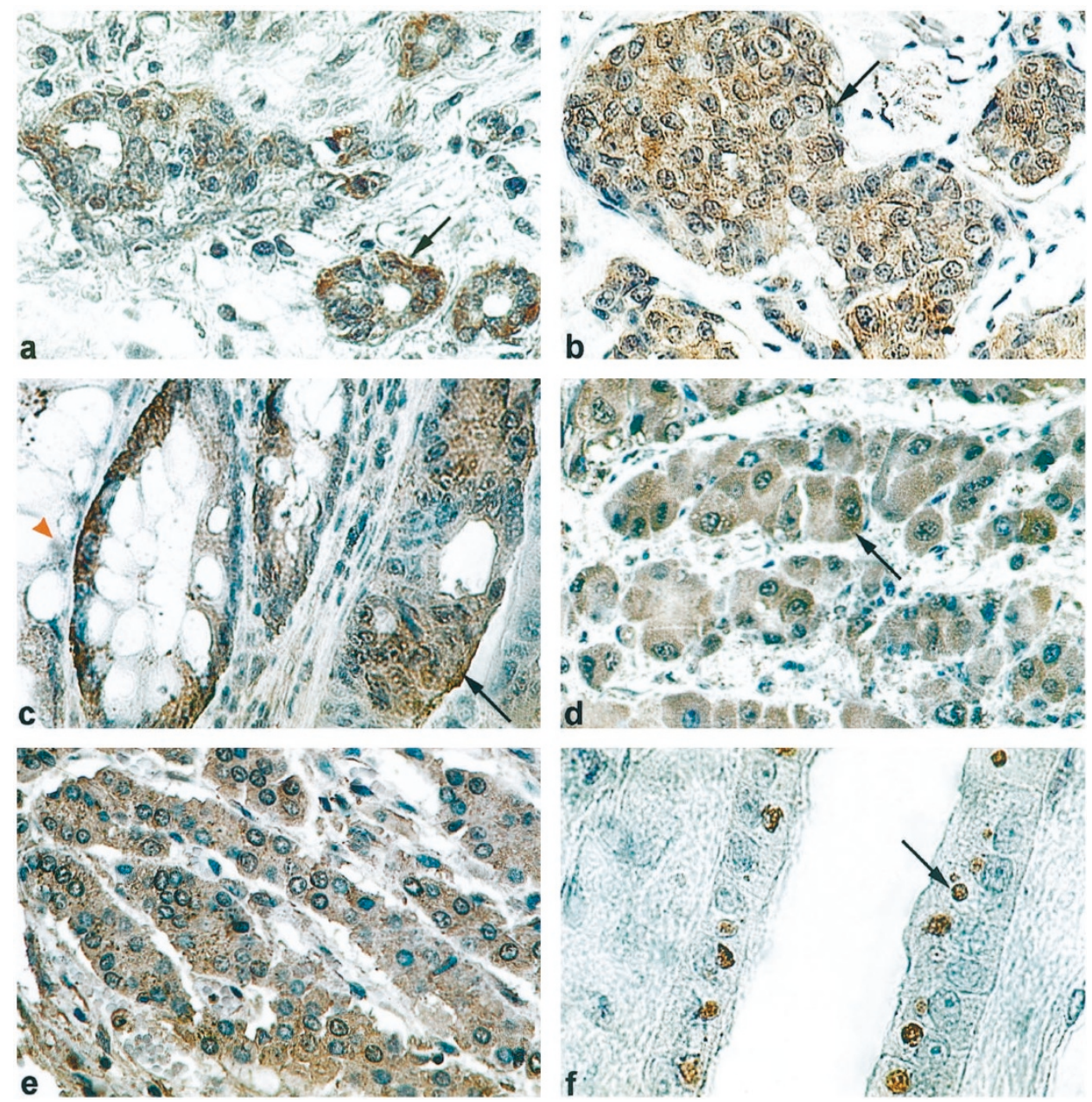

Figure 6.

Immunohistochemical staining with antibody 103/51 on different cancerous and normal tissues. The staining of antibody 103/51 on the following tissues is shown: carcinoma of the ampulla of Vater (a), mamma carcinoma invasive lobular (b), adenocarcinoma of the colon and no staining of normal beaker cell of the colon epithelia (c), hepatocellular carcinoma (d), glomerular and fascicular zones of the adrenal gland (e), collecting tubes of the kidney-specific staining of the Golgi apparatus (arrow) (f). Arrows in a to d indicate tumor cells, the red arrow in Panel $\mathrm{c}$ indicates beaker cells, and the arrow in Panel $\mathrm{f}$ indicates Golgi apparatus (original magnification; Panels a to e, $\times 400$, Panel $f, \times 200$ ).

standard assay for proliferation (Carmichael et al, 1987). To further investigate the stimulating properties of antibody 103/51, we incubated the cell line 23132 with various concentrations of purified antibody. We found a concentration-dependent stimulation with the highest activity at $4 \mu \mathrm{g} / \mathrm{mL}$ (Fig. 7a). Higher concentrations showed a slight decrease in stimulation.

To test if the murine antibody 58/47-69 has the same effects on cell growth, we performed the MTTstimulation assay with purified antibodies in comparable amounts. As can be seen in Figure $7 \mathrm{~b}$, both antibodies led to the stimulation of cell line 23132 in vitro. This further confirms identical specificity of both antibodies.

To confirm that the stimulation of antibody 103/51 and the murine antibody 58/47-69 is mediated by binding to CFR-1, we transfected cells with control vector PHOOK-2 and CFR-1 antisense vector and tested transfected cells in the MTT-assay. As a positive control for transfection, cells were also transfected with pHOOK-2-lacZ vector followed by $\beta$-galactosidase staining (not shown). Because com- parable stimulation was observed in nontransfected cells and cells transfected with control vector pHOOK-2, a reduction of the stimulating effect of both antibodies by the transfection procedure can be excluded. In contrast, cells transfected with CFR-1 antisense vector clearly show a reduced stimulation (Fig. 7c).

Finally, to demonstrate that the stimulation by antibody $103 / 51$ is not mediated by receptors other than CFR-1, we performed a MTT-stimulation assay with the cell line 23132 and compared it with the CFR-1negative lung carcinoma cell lines Colo-699 and EPLC-272H. Although the cell line 23132 is stimulated as described above, the two lung carcinoma cell lines did not show any stimulation by antibody $103 / 51$ (Fig. 7d), confirming the results observed in the immunohistochemistry.

\section{Discussion}

The autoantibody $103 / 51$, isolated from a patient with an adenocarcinoma of the stomach, binds to a 
Table 1. Reaction Pattern of Antibody 103/51 with Tumor Tissues

\begin{tabular}{llc}
\hline \multicolumn{1}{c}{ Tissue } & \multicolumn{1}{c}{ Carcinoma Type } & Antibody Staining \\
\hline Esophagus & Squamous & + \\
Stomach & Adeno (diffuse) & ++ \\
Stomach & Adeno (intestinal) & + \\
Colon & Adeno & + \\
Rectum & Adeno & + \\
Liver & Adeno (HCC) & ++ \\
Gallbladder & Adeno & + \\
Pancreas & Adeno (ductal) & + \\
Papilla of Vater & Adeno & + \\
Lung & Large cell anaplastic & - \\
Lung & Small cell & - \\
Lung & Adeno & ++ \\
Bronchus & Squamous epithelium & + \\
Mamma & Invasive (ductal) & + \\
Mamma & Invasive (lobular) & + \\
\hline
\end{tabular}

HCC, hepatocellular carcinoma.

Antibody staining was scored as follows: -, no staining; +, moderate staining; ++ , intensive staining.

membrane-bound variant of CFR-1 and enhances proliferation of tumor cells by binding to an $\mathrm{N}$-linked carbohydrate residue. We show that CFR-1 is overexpressed on a variety of malignant cells and on precursor lesions of gastric carcinoma. We speculate that this functional autoantibody mimics the effect of a natural ligand, influences the cell cycle control of the epithelial cell, and might be involved in the carcinogenesis of stomach carcinoma.

The molecular mechanisms of gastric carcinogenesis are relatively unknown, although a number of genetic abnormalities and some environmental influences such as alcohol, highly salted food, and bacterial infections $(H$. pylori) have been identified as risk factors for the development of gastric cancer (Correa, 1992). However, recent studies have shown that, at least for diffuse-type gastric cancer, a genetic predisposition might also exist (Guilford et al, 1998) and that autoantibodies might be involved in malignant processes.

The step-by-step process in the development of stomach cancer also starts with epithelial lesions, such as gastritis, peptic ulcer, and dysplasia induced by $H$. pylori and other carcinogens (Correa, 1992). In addition to the cellular changes induced by the $H$. pylori proteins, it has become clear in recent years that the bacterial infection and the development of gastritis and stomach cancer are accompanied by autoimmunity (Appelmelk and Negrini, 1997; Faller et al, 1997), which may also lead to degenerative processes of the stomach mucosa (Negrini et al, 1991).

We have recently shown that stimulating antibodies like the one described here frequently occur in stomach cancer patients, and also that 4 of 11 tumorreactive monoclonal antibodies lead to cell stimulation (Hensel et al, 1999b; Vollmers et al, 1994). Common antigens of the stomach mucosa are the gastric $\mathrm{H}+$ / $\mathrm{K}(+)$-ATPase (Toh et al, 1990) and Lewis blood group
Table 2. Reaction Pattern of Antibody 103/51 with Normal Tissues

\begin{tabular}{|c|c|c|}
\hline Tissue & Cell Type & $\begin{array}{l}\text { Antibody } \\
\text { Staining }^{a}\end{array}$ \\
\hline Salivary gland & Glandular & - \\
\hline $\begin{array}{l}\text { Stomach (non } \\
\text { inflammated) }\end{array}$ & Glandular & - \\
\hline $\begin{array}{l}\text { Stomach }(\mathrm{H} . \text { pylori } \\
\text { infected) }\end{array}$ & Glandular & $+{ }^{b}$ \\
\hline $\begin{array}{l}\text { Stomach (high grade } \\
\text { dysplasia) }\end{array}$ & Glandular & $++{ }^{b}$ \\
\hline Duodenum & Glandular & - \\
\hline Colon & Epithelial & - \\
\hline Rectum & Glandular & - \\
\hline Pancreas & Glandular & - \\
\hline Liver & Glandular & - \\
\hline Gallbladder & Glandular & - \\
\hline Oral mucosa & Squamous epithelium & - \\
\hline Anal mucosa & Squamous epithelium & - \\
\hline Skin & Keratinocyte, glandular & - \\
\hline Mamma & Glandular & - \\
\hline Larynx & Epithelial & - \\
\hline Bronchus & Epithelial & - \\
\hline Lung & Glandular, alveolar & - \\
\hline Thyroid gland & Glandular & - \\
\hline Adenohypophysis & Glandular & - \\
\hline Adrenal gland & Glandular & $++^{c}$ \\
\hline Testis & Glandular & - \\
\hline Ovary & Glandular & - \\
\hline Prostate & Glandular & - \\
\hline Urothelium & Epithelial & - \\
\hline Kidney & Epithelial & $++^{d}$ \\
\hline Thymus & Lymphatic & - \\
\hline Spleen & Lymphatic & - \\
\hline Lymph node & Lymphatic & - \\
\hline Cerebral cortex & Neural & - \\
\hline $\begin{array}{l}\text { Peripheric neural } \\
\text { ganglia }\end{array}$ & Neural & - \\
\hline \multicolumn{3}{|c|}{$\begin{array}{l}{ }^{a} \text { Antibody staining was scored as follows: }-, \text { no staining; }+ \text {, moderate } \\
\text { staining; }++ \text {, intensive staining. } \\
{ }^{b} \text { Proliferation zone, Glandular foveola. } \\
{ }^{c} \text { Glomerular, fascicular zone (membranous staining). } \\
{ }^{d} \text { Collecting tubes of the endoplasmatic reticulum. }\end{array}$} \\
\hline
\end{tabular}

antigens (Appelmelk et al, 1997). These autoantibodies often consist of so-called natural antibodies, which are in germline configuration and do not undergo affinity maturation (Dighiero, 1995). Antibody $103 / 51$ is a nonmature germline-coded (natural) autoantibody (Hensel et al, 1999b) that stimulates stomach carcinoma cells in a concentration-dependent manner. Using glycosidase experiments, we were able to show that the epitope is an $\mathrm{N}$-linked carbohydrate residue. This is in accordance with other results on tumorbinding human antibodies, which also bind carbohydrate residues (Karsten et al, 1998; Hensel et al, 1999a). One reason for this is that sugars are specifically overexpressed or modified on tumors (Ho et al, 1995).

The protein was characterized as CFR- 1 by purification, sequencing, and transfection experiments. The 


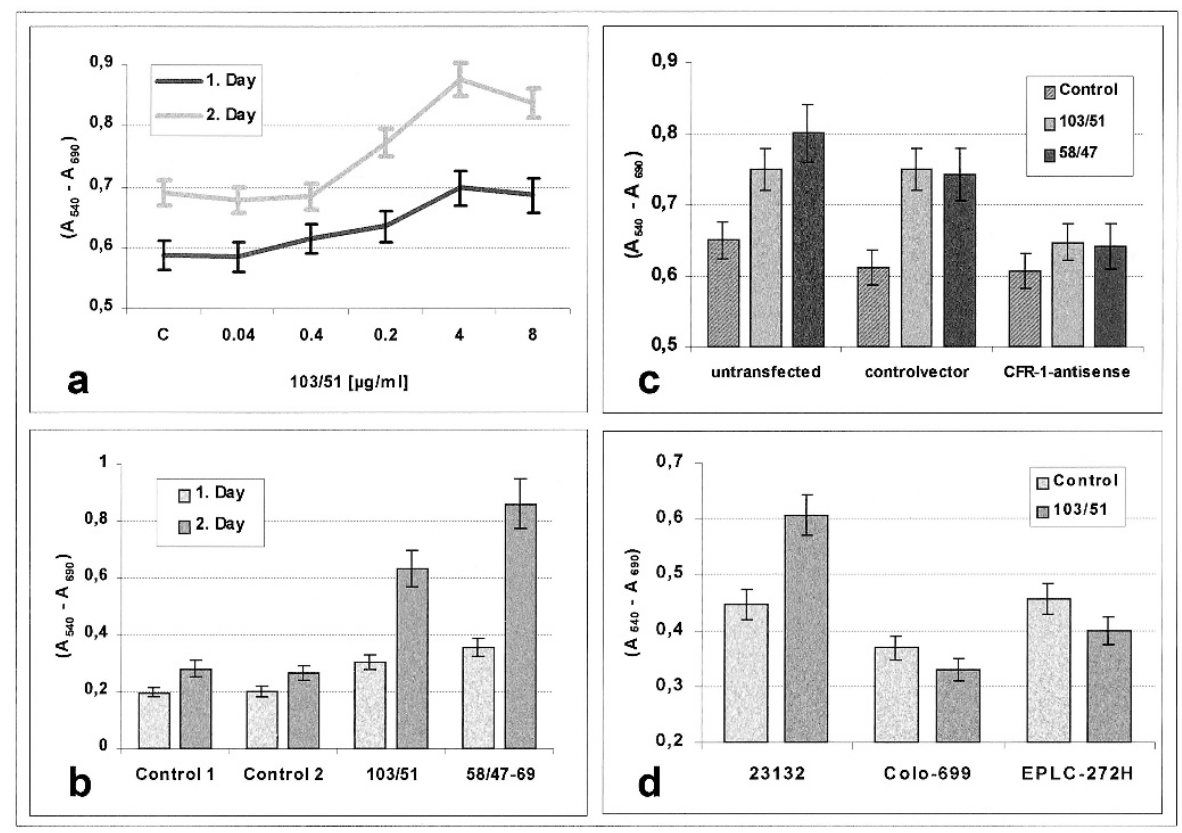

Figure 7.

Stimulation of cell lines with antibodies 103/51 and 58/47-69 determined by colorimetric MTT-assay. a, Titration with purified antibody 103/51 shows an increase in stimulation up to $4 \mu \mathrm{g} / \mathrm{mL}$. Higher concentrations do not lead to higher stimulation ( $c$, control, no antibody added). b, A MTT-assay with equal concentrations (4 $\mu \mathrm{g} / \mathrm{mL}$ ) of purified antibodies 103/51 and 58/47-69 shows comparable stimulation of tumor cell 23132 after one or two days of incubation (Control 1, Chromopure human IgM; Control 2, unrelated mouse IgM). c, Cell line 23132 was transiently transfected with control vector pH0OK-2 or CFR-1 antisense vector, incubated for 24 hours, and tested in the MTT assay for stimulation with $4 \mu \mathrm{g} / \mathrm{mL}$ purified antibody 103/51 after 24 hours. Untransfected cells were also incubated as control (Control, unrelated human IgM). d, A MTT-assay, with equal concentrations (4 $\mu \mathrm{g} / \mathrm{mL}$ ) of antibody 103/51, on different epithelial tumor cell lines shows stimulation only on the CFR-1-positive cell line 2313224 hours after addition of antibody. CFR-1-negative cell lines Colo-699 and EPLC-272H do not show any stimulation by antibody $103 / 51$

specificity of $103 / 51$ was strengthened by the production of a murine antibody against the purified molecule with identical reactivity and function, immunohistochemical stainings, and in MTT-assay of two CFR-1negative cell lines. The CFR- 1 molecule, detected by both human and murine antibodies, is clearly located in the cell membrane of epithelial cells and has a tissue expression pattern different from the ones described so far for CFR-1 (Burrus et al, 1992).

CFR-1, which was isolated as a high-affinity fibroblast growth factor (FGF)-binding protein from chicken fibroblasts (Burrus et al, 1992), binds to a number of FGF and may have a role in the regulation of cellular proliferation. In Chinese hamster ovary cells $(\mathrm{CHO}), \mathrm{CFR}-1$ was found to be expressed only in the Golgi apparatus (Burrus et al, 1992), but it can also be secreted in a mutated form (Zuber et al, 1997). Depending on the organism, two detected variants of CFR-1, ESL-1 and MG-160, share sequence homologies between $88 \%$ and 95\% (Burrus et al, 1992; Mourelatos et al, 1996; Steegmaier et al, 1995; Stieber et al, 1995) and do not appear to share any sequence homologies to other known proteins. Function and cellular distribution of CFR-1 and the homologues is relatively unknown and contradictory. It has been shown that MG-160, which is a medial Golgi sialoglycoprotein and was purified from rat brains, plays a role in intracellular FGF trafficking (Zuber et al, 1997).

Recent findings have shown that the localization of this protein is not restricted to the Golgi apparatus. However, if truncated at the c-terminus, protein can be delivered to the plasma membrane and filopodia (Gonatas et al, 1998). This is consistent with the finding that the third homolog, ESL-1, which was isolated from mouse neutrophilic progenitor cells (32Dcl3), is located in the Golgi apparatus as well on the cell surface of the microvilli (Gonatas et al, 1998; Steegmaier et al, 1997). ESL-1 was identified as ligand for E-selectin in neutrophils with an apparent molecular mass of $150 \mathrm{kd}$. Immunoprecipitation with antiESL-1 antibodies showed that an undefined isoform of this protein could be precipitated from various cells, including some cancerous cell lines (Steegmaier et al, 1995).

Because of the predominantly membranous distribution of CFR-1 in cancerous cells described in this paper, we conclude that the receptor described here is a new variant of CFR-1. A variable cellular distribution of CFR-1 and its homolog is possible, due to the above-mentioned results, and is a known phenomenon for other proteins (Smalheiser, 1996). An altered distribution might be caused by a different glycosylation pattern in malignant cells, which may lead to a transport to the plasma membrane.

The tissue distribution shows that the CFR-1 molecule is correlated with cellular activation and proliferation demonstrated by staining with antibody Ki67 (Ramires et al, 1997). Normal differentiated stomach mucosa do not express this receptor in a measurable amount, but $H$. pylori-infiltrated epithelia and dysplastic epithelia have this antigen. Both tissues are proliferative and are precursors for gastric carcinoma. 
The proliferation of mucosal tissue might be induced by the bacteria, by autoantibodies, or both. For $H$. pylori it has been proved that they stimulate cell growth or induce transformation, but there is also clear evidence that autoantibodies are involved in the development of various diseases, for example, celiac disease (Dieterich et al, 1997), rheuma, and possibly ulcerative colitis (Targan et al, 1995). These diseases are often accompanied by inflammatory processes and sometimes may end in malignant events (Kipps and Carson, 1993). Our data strongly support the hypothesis that autoantibodies can act as ligands for growth receptors, stimulate cell growth, and induce malignant processes that may lead to stomach cancer.

\section{Materials and Methods}

\section{Cell Culture and Antibody Purification}

For all assays, the established stomach adenocarcinoma cell line 23132 (Hensel et al, 1999b) was used. Cells were grown to $80 \%$ confluency in RPMI-1640 (PAA, Vienna, Austria) supplemented with 10\% FCS and penicillin/streptomycin (1\% for both). For the assays described, cells were detached with trypsin/ EDTA and washed twice with phosphate buffered saline (PBS) before use. The human hybridoma cell line 103/51 was produced and grown as described (Vollmers et al, 1994). Purification of the lgM antibodies was performed as described elsewhere (Vollmers et al, 1998).

\section{Preparation of Membrane Extracts}

Isolation of membrane proteins from tumor cells was performed as described by Hensel et al (1999b), using cell line 23132. In short, confluent tumor cells were washed twice with PBS, harvested with a cellscraper and centrifuged, and resuspended in hypotonic buffer (20 mm HEPES, $3 \mathrm{~mm} \mathrm{KCl,} 3 \mathrm{~mm} \mathrm{MgCl}_{2}$ ). After 15 minutes' incubation on ice followed by sonification for 5 minutes, the nuclei were pelleted by centrifugation at $10,000 \times g$ for 10 minutes. The supernatant was centrifuged for 30 minutes at $100,000 \times g$ in a swing-out rotor to pellet membranes. After washing the pellet with hypotonic buffer, it was resuspended in membrane lysis buffer (50 mm HEPES pH 7.4, $0.1 \mathrm{~mm}$ EDTA, 10\% glycerol, and 1\% Triton X-100). Complete protease inhibitor (Boehringer, Mannheim, Germany) was added to all solutions.

\section{Western Blotting}

Ten percent reducing SDS-PAGE gels and Western blotting of proteins were performed using standard protocols as described elsewhere (Hensel et al, 1999b). In short, blotted nitrocellulose membranes were blocked with PBS containing $2 \%$ low fat milk powder, followed by a 1-hour incubation with 10 $\mu \mathrm{g} / \mathrm{mL}$ purified antibody $103 / 51$. The secondary antibody (peroxidase-coupled rabbit anti-human IgM antibody; Dianova, Hamburg, Germany) was detected with the SuperSignal chemiluminescence kit from Pierce (KMF, St. Augustin, Germany).

\section{Purification of the Antigen 103/51}

The purification of the antigens was performed by column chromatography using a Pharmacia (Freiburg, Germany) FPLC unit. For size exclusion chromatography, a Pharmacia Superdex 200 column (XK16/60) was loaded with $5 \mathrm{mg}$ membrane preparation and run with buffer A (100 mm Tris/Cl, pH 7.5, 2 mm EDTA, 40 $\mathrm{mm} \mathrm{NaCl}, 1 \%$ Triton $\mathrm{X}-100)$. Then the eluate was fractionated and examined by Western blot analysis for reaction with antibody 103/51. Positive fractions were loaded on a MonoQ (5/5) column using buffer A. The bound proteins were eluated with a linear gradient using buffer B (100 mm Tris/Cl, pH 7.5, $1 \mathrm{~m} \mathrm{NaCl,} 2$ mм EDTA, $1 \mathrm{~m} \mathrm{NaCl}, 1 \%$ Triton $\mathrm{X}-100)$, fractionalized, and examined in Coomassie-stained SDS-PAGE and Western blot analysis. Positive bands were cut out from gel and sequenced or used for immunization of mice.

\section{MALDI Peptide Mapping}

The band of interest was excised and cut into small pieces of about $1 \mathrm{~mm} \times 1 \mathrm{~mm}$. Gel pieces were washed, reduced with dithiothreitol (DTT), S-alkylated with iodoacetamide, and in-gel digested with trypsin (unmodified, sequencing grade, Boehringer) as described elsewhere (Shevchenko et al, 1996b). After 3 hours of digestion at $37^{\circ} \mathrm{C}, 0.3 \mu \mathrm{L}$ of the digest solution was removed and subjected to MALDI peptide mass mapping on a Bruker Reflex MALDI-TOF equipped with delayed extraction (Bruker-Franzen, Bremen, Germany). The thin film technique was adopted for sample preparation (Jensen et al, 1996). The tryptic peptide masses were used to search a nonredundant protein sequence database by the PeptideSearch software program developed in-house.

\section{Cloning of CFR-1 Antisense Vector and Transfection}

RNA isolation, cDNA synthesis, and PCR were performed as described (Hensel et al, 1999b). In short, for PCR for amplification of a 897-bp fragment ranging from base pairs 802 to 1699, the following primers were used: CFR-For 5' GCTTGGAGAAAGGCCTGGTGAA 3', CFR-Rev 5' TGGCACTTGCGGTACAGGACAG 3'. Amplification was performed using the following cycle profile: $95^{\circ} \mathrm{C}, 2$ minutes, followed by 35 cycles of $94^{\circ} \mathrm{C}, 30$ seconds; $60^{\circ} \mathrm{C}, 30$ seconds; $72^{\circ} \mathrm{C}, 60$ seconds; and a final extension of $72^{\circ} \mathrm{C}$ for 4 minutes. Cloning into the pCR-Script Amp SK $(+)$ vector and DNA sequencing were performed as previously described (Hensel et al, 1999b). The insert was subcloned into the pHook-2 vector (Invitrogen, Leek, The Netherlands), and cloning was controlled again by sequencing.

Transfection of cell line 23132 with pHOOK2-antiCFR-1 was accomplished with PrimeFector reagent (PQLab, Erlangen, Germany) according to the supplier's manual. In short, plasmid DNA was diluted to 10 
$\mu \mathrm{g} / \mathrm{mL}$ and PrimeFector reagent to $1: 10$ in serum-free growth medium. Diluted plasmid DNA $(450 \mu \mathrm{L})$, diluted PrimeFector reagent $(90 \mu \mathrm{L})$, and serum-free medium (460 $\mu \mathrm{L}$ ) were mixed and incubated at room temperature (RT). Sixty-millimeter cell culture plates $(70 \%$ confluent) were washed twice with serum-free medium, and then the PrimeFector/DNA mixture was added dropwise. Cells were incubated 18 hours at $37^{\circ} \mathrm{C}$ and $7 \% \mathrm{CO}_{2}$, then serum-free growth medium was replaced with growth medium containing $10 \%$ FCS, and cells were incubated another 24 hours before studying CFR-1 expression.

\section{Flow Cytometry}

The cell line 23132 was detached from culture plates by trypsin/EDTA 48 hours after transfection, washed, and subsequently incubated on ice with antibody $103 / 51$ and human isotype-matched control antibody (Chromopure human IgM) for 15 minutes, followed by incubation with a FITC-labeled rabbit anti-human IgM antibody (Dianova) for 15 minutes on ice. Antibodies were optimally diluted in PBS containing $0.01 \%$ sodiumazide. Cells were analyzed by flow cytometry (FACScan; Becton Dickinson, San Jose, California).

\section{Glycosidase Assays}

Detached and washed cells were resuspended in RPMI-1640 containing 10\% FCS and incubated for 1 hour on ice, counted, and cytospins were prepared. After air-drying, cytospin preparations were acetonefixed (10 minutes), washed, and incubated with 20 $\mu \mathrm{U} / \mathrm{mL}$ O-glycosidase or $5 \mathrm{mU} / \mathrm{mL} \mathrm{N}$-glycosidase (Boehringer) for 4 hours at $37^{\circ} \mathrm{C}$. Then slides were washed and immunohistochemically stained.

For deglycosylation of membranous proteins, membrane extracts were incubated for 16 hours at $37^{\circ} \mathrm{C}$ with $1 \mathrm{mU} / \mathrm{mL} \mathrm{N}$-glycosidase diluted in deglycosylation buffer (50 mM $\mathrm{PO}_{4}$-buffer, $\mathrm{pH}$ 7.4). As a control, extracts were incubated with deglycosylation buffer alone. Then, extracts were separated by SDS-PAGE and Western blots were performed as described above.

\section{Production of Murine Monoclonal Antibodies}

BALB/c mice were immunized twice within 17 days with $5 \mu \mathrm{g}$ purified antigen of antibody 103/51, and killed 4 days after the second immunization. Spleens were disrupted mechanically and fused with $1 \times 10^{7}$ NSO cells as described earlier (Vollmers et al, 1985). Antibody-producing hybridomas were tested and selected for immunohistochemical staining and reaction in Western blot analysis. Clone 58/47-69 with positive reactivity was used for further experiments.

\section{Immunohistochemical Staining of Paraffin Sections}

Paraffin-embedded human gastric mucosa and tumor were sectioned $(5 \mu \mathrm{m})$, deparaffinized, and blocked with BSA (15 mg/mL) diluted in PBS for 30 minutes. The sections were incubated with supernatant of hybridoma
103/51, or 58/47-69, Ki67 (Loxo, Dossenhein, Germany) or mouse anticytokeratin 8 antibody diluted 1:15 with BSA/PBS (Dako, Hamburg, Germany) for 2 hours in a humidified incubator. Sections were then washed three times with $\mathrm{Tris} / \mathrm{NaCl}$, followed by incubation with peroxidase-labeled rabbit anti-human or rabbit antimouse conjugate (Dako) diluted 1:50 in PBS containing rabbit serum (for antibody 103/51) or in PBS containing human AB plasma (for antibody 58/47-69 and anticytokeratin). After washing three times with $\mathrm{Tris} / \mathrm{NaCl}$ and incubation in PBS for 10 minutes, staining was performed with diaminobenzidine $(0.05 \%)$-hydrogen peroxide $(0.02 \%)$ for 10 minutes at RT. The reaction was stopped under running tap water, and sections were counterstained with hematoxylin.

\section{Immunohistochemical Staining of Living and Acetone-Fixed Cells}

For living cell staining, cells were detached, washed, and diluted to $1 \times 10^{6}$ cells $/ \mathrm{mL}$. One milliliter of cell suspension was centrifuged at $1,500 \times g$ for 5 minutes. Antibody diluted to $40 \mu \mathrm{g} / \mathrm{mL}$ with complete RPMI was added to a final volume of $1 \mathrm{~mL}$ and incubated for 90 minutes on ice. Then cells were pelleted at $1,500 \times g$ for 5 minutes and resuspended with $500 \mu \mathrm{L}$ RPMI. With $200 \mu \mathrm{L}$ of the cell suspension, cytospin preparations were prepared and air-dried for 30 minutes. Cells were fixed in acetone for 10 minutes and washed with Tris $/ \mathrm{NaCl}$ three times. Horseradish peroxidase (HRP)-coupled rabbit anti-human IgM (DAKO) was diluted $1: 50$ in PBS/BSA $(0.1 \%)$ and incubated for 30 minutes at RT. After three washings, staining was performed as mentioned above.

For staining of acetone-fixed cells, cytospins were prepared, air-dried at RT and fixed in acetone as described above. Then, cytospins were blocked for 15 minutes with PBS/BSA $(0.1 \%)$ and incubated for 30 minutes with $10 \mu \mathrm{g} / \mathrm{mL}$ of primary antibodies followed by three washings. Incubation with secondary antibody and staining was performed as described above.

\section{MTT-Proliferation Assay}

The MTT-assay with the established cell line 23132 was performed as described (Vollmers et al, 1994). In short, trypsinized cells were diluted to $1 \times 10^{6}$ cells $/ \mathrm{mL}$ in complete growth medium, and $50 \mu$ l of cell suspension was added to each well of a 96-well plate. Then $50 \mu \mathrm{L}$ of the antibodies, diluted to the indicated concentrations with complete growth medium, were added to the wells, and plates were incubated for 1 or 2 days at $37^{\circ} \mathrm{C}$ in a humidified incubator. For measurement, $50 \mu \mathrm{L}$ of MTT (3[4, 5 dimethylthiazol]-2,5 diphenyltetrazolium bromide) solution $(5 \mathrm{mg} / \mathrm{mL})$ were added to each well, and plates were incubated for 30 minutes. After incubation, plates were centrifuged at $800 \mathrm{~g}$ for 5 minutes, MTT solution was removed, the stained cell pellet was dissolved in $150 \mu \mathrm{L}$ dimethylsulfoxide, and absorption was measured at wavelengths of $540 \mathrm{~nm}$ and $690 \mathrm{~nm}$. 


\section{Acknowledgements}

The authors thank Ms. E. Wozniak and Ms. T. Pohle for excellent technical assistance, Mr. E. Schmitt for preparing the artwork, and Ms. A. Stack for improving the manuscript.

\section{References}

Appelmelk BJ and Negrini R (1997). Helicobacter pylori and gastric autoimmunity. Curr Opin Gastroenterol 13:31-34.

Appelmelk BJ, Negrini R, Moran AP, and Kuipers EJ (1997). Molecular mimicry between Helicobacter pylori and the host. Trends Microbiol 5:70-73.

Burrus LW, Zuber ME, Lueddecke BA, and Olwin BB (1992). Identification of a cysteine-rich receptor for fibroblast growth factors. Mol Cell Biol 12:5600-5609.

Carmichael J, DeGraff WD, Gazdar AF, Minna JD, and Mitchell JB (1987). Evaluation of a tetrazolium-based semiautomated colorimetric assay: Assessment of chemosensitivity testing. Cancer Res 47:936-942.

Claeys D, Faller G, Appelmelk BJ, Negrini R, and Kirchner T (1998). The gastric $\mathrm{H}+, \mathrm{K}+$-ATPase is a major autoantigen in chronic Helicobacter pylori gastritis with body mucosa atrophy. Gastroenterology 115:340-347.

Correa P (1992). Human gastric carcinogenesis: A multistep and multifactorial process. First American Cancer Society Award Lecture on Cancer Epidemiology and Prevention. Cancer Res 52:6735-6740.

Crabtree JE, Peichl P, Wyatt JI, Stachl U, and Lindley IJ (1993). Gastric interleukin-8 and IgA IL-8 autoantibodies in Helicobacter pylori infection. Scand J Immunol 37:65-70.

Dieterich W, Ehnis T, Bauer M, Donner P, Volta U, Riecken EO, and Schuppan D (1997). Identification of tissue transglutaminase as the autoantigen of celiac disease. Nat Med 3:797-801.

Dighiero G (1995). Natural autoantibodies in humans: Their relevance in autoimmunity and lymphoproliferative disorders. Forum Trends Exp Clin Med 5:58-71.

Faller G, Steininger H, Kranzlein J, Maul H, Kerkau T, Hensen J, Hahn EG, and Kirchner T (1997). Antigastric autoantibodies in Helicobacter pylori infection: Implications of histological and clinical parameters of gastritis. Gut 41:619-623.

Fernandez-Madrid F, Karvonen RL, Kraut MJ, Czelusniak B, and Ager JW (1996). Autoimmunity to collagen in human lung cancer. Cancer Res 56:121-126.

Gonatas JO, Chen YJ, Stieber A, Mourelatos Z, and Gonatas NK (1998). Truncations of the c-terminal cytoplasmatic domain of MG160, a medial Golgi sialoprotein, result in its partial transport to the plasma membrane and filopodia. J Cell Sci 111:249-260.

Gonatas JO, Mezitis SG, Stieber A, Fleischer B, and Gonatas NK (1989). MG-160: A novel sialoglycoprotein of the medial cisternae of the Golgi apparatus. J Biol Chem 264:646-653.

Guilford P, Hopkins J, Harraway J, McLeod M, McLeod N, Harawira P, Taite H, Scoular R, Miller A, and Reeve AE (1998). E-cadherin germline mutations in familial gastric cancer. Nature 392:402-405.

Hensel F, Hermann R, Schubert C, Abé N, Schmidt K, Franke A, Shevchenko A, Mann M, Müller-Hermelink HK, and Vollmers HP (1999a). Characterization of glycosylphosphatidylinositollinked molecule CD55/decay-accelerating factor as the recep- tor for antibody SC-1-induced apoptosis. Cancer Res 59:52995306.

Hensel F, Knörr C, Hermann R, Krenn V, Müller-Hermelink HK, and Vollmers HP (1999b). Mitogenic autoantibodies in Helicobacter pylori-associated stomach cancerogenesis. Int J Cancer 81:229-235.

Ho SB, Shekels LL, Toribara NW, Kim YS, Lyftogt C, Cherwitz DL, and Niehans GA (1995). Mucin gene expression in normal, preneoplastic, and neoplastic human gastric epithelium. Cancer Res 55:2681-2690.

Jensen ON, Podtelejnikov A, and Mann M (1996). Delayed extraction improves specificity in database searches by matrix-assisted laser desorption/ionization peptide maps. Rapid Commun Mass Spectrom 10:1371-1378.

Karsten U, Diotel C, Klich G, Paulsen H, Goletz S, Müller S, and Hanisch FG (1998). Enhanced binding of antibodies to the DTR motif of MUC1 tandem repeat peptide is mediated by site-specific glycosylation. Cancer Res 58:2541-2549.

Kipps TJ and Carson DA (1993). Autoantibodies in chronic lymphocytic leukemia and related systemic autoimmune diseases. Blood 81:2475-2487.

Logan RP (1994). Helicobacter pylori and gastric cancer. Lancet 344:1078-1079.

Ma JY, Borch K, Sjostrand SE, Janzon L, and Mardh S (1994). Positive correlation between $\mathrm{H}, \mathrm{K}$-adenosine triphosphatase autoantibodies and Helicobacter pylori antibodies in patients with pernicious anemia. Scand J Gastroenterol 29:961-965.

Mourelatos Z, Gonatas JO, Cinato E, and Gonatas NK (1996). Cloning and sequence analysis of the human MG160, a fibroblast growth factor and E-selectin binding membrane sialoglycoprotein of the Golgi apparatus. DNA Cell Biol 15:1121-1128.

Negrini R, Lisato L, Zanella I, Cavazzini L, Gullini S, Villanaci V, Poiesi C, Albertini A, and Ghielmi S (1991). Helicobacter pylori infection induces antibodies cross-reacting with human gastric mucosa. Gastroenterol 101:437-445.

Negrini R, Savio A, Poiesi C, Appelmelk BJ, Buffoli F, Paterlini A, Cesari P, Graffeo M, Vaira D, and Franzin G (1996). Antigenic mimicry between Helicobacter pylori and gastric mucosa in the pathogenesis of body atrophic gastritis. Gastroenterol 111:655-665.

Peyrat JP, Bonneterre J, Lubin R, Vanlemmens L, Fournier J, and Soussi T (1995). Prognostic significance of circulating P53 antibodies in patients undergoing surgery for locoregional breast cancer. Lancet 345:621-622.

Pupa SM, Menard S, Andreola S, and Colnaghi MI (1993). Antibody response against the c-erbB-2 oncoprotein in breast carcinoma patients. Cancer Res 53:5864-5866.

Rajkumar T and Gullick WJ (1994). A monoclonal antibody to the human c-erbB3 protein stimulates the anchorageindependent growth of breast cancer cell lines. $\mathrm{Br} \mathrm{J}$ Cancer 70:459-465.

Ramires M, David L, Leitao D, Seixas M, Sansonetty F, and Sobrinho-Simoes M (1997). Ki67 labelling index in gastric carcinomas: An immunohistochemical study using double staining for the evaluation of the proliferative activity of diffuse-type carcinomas. J Pathol 182:62-67. 
Schlichtholz B, Legros Y, Gillet D, Gaillard C, Marty M, Lane D, Calvo F, and Soussi T (1992). The immune response to p53 in breast cancer patients is directed against immunodominant epitopes unrelated to the mutational hot spot. Cancer Res 52:6380-6384.

Shevchenko A, Jensen ON, Podtelejnikov AV, Sagliocco F, Wilm M, Vorm O, Mortensen P, Boucherie $\mathrm{H}$, and Mann M (1996a). Linking genome and proteome by mass spectrometry: Large-scale identification of yeast proteins from two dimensional gels. Proc Natl Acad Sci USA 93:14440-14445.

Shevchenko A, Wilm M, Vorm O, and Mann M (1996b). Mass spectrometric sequencing of proteins silver-stained polyacrylamide gels. Anal Chem 68:850-858.

Smalheiser NR (1996). Proteins in unexpected locations. Mol Biol Cell 7:1003-1014.

Steegmaier M, Borges E, Berger J, Schwarz H, and Vestweber D (1997). The E-selectin-ligand ESL-1 is located in the Golgi as well as on microvilli on the cell surface. J Cell Sci 110:687-694.

Steegmaier M, Levinovitz A, Isenmann S, Borges E, Lentner M, Kocher HP, Kleuser B, and Vestweber D (1995). The E-selectin-ligand ESL-1 is a variant of a receptor for fibroblast growth factor. Nature 373:615-620.

Steininger $H$, Faller $G$, Dewald $E$, Brabletz $T$, Jung $A$, and Kirchner T (1998). Apoptosis in chronic gastritis and its correlation with antigastric autoantibodies. Virchows Arch 433:1318.

Stieber A, Mourelatos Z, Chen YJ, Le Douarin N, and Gonatas NK (1995). MG160, a membrane protein of the Golgi apparatus which is homologous to a fibroblast growth factor receptor and to a ligand for E-selectin, is found only in the Golgi apparatus and appears early in chicken embryo development. Exp Cell Res 219:562-570.

Takahashi M, Chen W, Byrd DR, Disis ML, Huseby ES, Qin H, McCahill L, Nelson H, Shimada H, and Okuno K (1995). Antibody to ras proteins in patients with colon cancer. Clin Cancer Res 1:1071-1077.

Targan SR, Landers CJ, Cobb L, MacDermott RP, and Vidrich A (1995). Perinuclear anti-neutrophil cytoplasmic antibodies are spontaneously produced by mucosal B cells of ulcerative colitis patients. J Immunol 155:3262-3267.
Toh BH, Gleeson PA, Simpson RJ, Moritz RL, Callaghan JM, Goldkorn I, Jones CM, Martinelli TM, Mu FT, Humphris DC, Pettitt JM, Mori Y, Masuda T, Sobieszczuk P, Weinstock J, Mantamadiotis T, and Baldwin GS (1990). The 60- to 90-kDa parietal cell autoantigen associated with autoimmune gastritis is a beta subunit of the gastric $\mathrm{H}+/ \mathrm{K}(+)$ - ATPase (proton pump). Proc Natl Acad Sci USA 87:6418-6422.

Tomer $Y$, Sherer $Y$, and Shoenfeld $Y$ (1998). Autoantibodies, autoimmunity and cancer. Oncol Rep 5:753-761.

Velikova G, Banks RE, Gearing A, Hemingway I, Forbes MA, Preston SR, Jones M, Wyatt J, Miller K, Ward U, Al-Maskatti J, Singh SM, Ambrose NS, Primrose JN, and Selby PJ (1997). Circulating soluble adhesion molecules E-cadherin, E-selectin, intercellular adhesion molecule-1 (ICAM-1) and vascular cell adhesion molecule-1 (VCAM-1) in patients with gastric cancer. $\mathrm{Br} J$ Cancer 76:1398-1404.

Vollmers HP, Dämmrich J, Ribbert H, Grassel S, Debus S, Heesemannn J, and Müller-Hermelink HK (1994). Human monoclonal antibodies from stomach carcinoma patients react with Helicobacter pylori and stimulate stomach cancer cells in vitro. Cancer 74:1525-1532.

Vollmers HP, Imhof B, Wieland I, and Birchmeier W (1985). Monoclonal antibodies NORM-1 and NORM-2 induce more normal behaviour in tumor cells in vitro and in vivo. Cell 40:547-557.

Vollmers HP, Zimmermann U, Krenn V, Timmermann W, Illert B, Hensel F, Hermann R, Thiede A, Wilhelm M, Rückle-Lanz H, Reindl L, and Müller-Hermelink HK (1998). Adjuvant therapy for gastric adenocarcinoma with the apoptosis-inducing human monoclonal antibody SC-1: First clinical and histopathological results. Oncol Rep 5:549-552.

Winter SF, Minna JD, Johnson BE, Takahashi T, Gazdar AF, and Carbone DP (1992). Development of antibodies against p53 in lung cancer patients appears to be dependent on the type of p53 mutation. Cancer Res 52:4168-4174.

Yamamoto A, Shimizu E, Ogura T, and Sone S (1996). Detection of auto-antibodies against L-myc oncogene products in sera from lung cancer patients. Int J Cancer 69:283-289.

Zuber ME, Zhou Z, Burrus LW, and Olwin BB (1997). Cysteine-rich FGF receptor regulates intracellular FGF-1 and FGF-2 levels. J Cell Physiol 170:217-227. 